2010-01-01

\title{
Differential Genome-Wide Array-Based Methylation Profiles in Prognostic Subsets of Chronic Lymphocytic Leukemia
}

\author{
Meena Kanduri \\ Uppsala Universitet \\ Nicola Cahill \\ Technological University Dublin, nicola.cahill@genpat.uu.se \\ Hanna Göransson \\ Uppsala Universitet
}

See next page for additional authors

Follow this and additional works at: https://arrow.tudublin.ie/scschbioart

Part of the Genetic Phenomena Commons, Medical Genetics Commons, and the Oncology Commons

\section{Recommended Citation}

Kanduri, M. et al. (2011) Differential genome-wide array-based methylation profiles in prognostic subsets of chronic lymphocytic leukemia. Blood. 2010 Jan 14;115(2):296-305 doi:10.1182/blood-2009-07-232868

This Article is brought to you for free and open access by the School of Biological Sciences at ARROW@TU Dublin. It has been accepted for inclusion in Articles by an authorized administrator of ARROW@TU Dublin. For more information, please contact arrow.admin@tudublin.ie, aisling.coyne@tudublin.ie,gerard.connolly@tudublin.ie. Funder: ABBEST

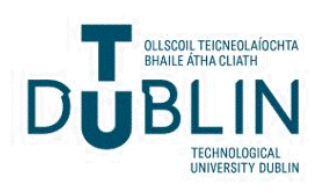




\section{Authors}

Meena Kanduri, Nicola Cahill, Hanna Göransson, Camilla Enström, Fergus Ryan, Anders Isaksson, and Richard Rosenquist 
Differential genome-wide array-based methylation profiles in prognostic subsets of chronic lymphocytic leukemia

Meena Kanduri ${ }^{1}$, Nicola Cahill ${ }^{1,4}$, Hanna Göransson ${ }^{2}$, Camilla Enström $^{3}$, Fergus Ryan ${ }^{4}$, Anders Isaksson $^{2}$ and Richard Rosenquist ${ }^{1 \#}$

${ }^{1}$ Department of Genetics and Pathology, Uppsala University, Uppsala, Sweden

${ }^{2}$ Department of Medical Sciences, Cancer Pharmacology and Informatic, Uppsala University, Uppsala, Sweden

${ }^{3}$ Department of Medical Sciences, Molecular Medicine, Uppsala University, Uppsala, Sweden

${ }^{4}$ School of Biological Sciences, Dublin Institute of Technology (DIT), Dublin, Ireland

* These authors contributed equally to this work.

Running title: Genome-wide methylation profiles in CLL

Scientific heading: NEOPLASIA

Word counts: Total count: 4097; Abstract: 204

\section{\# Corresponding author:}

Richard Rosenquist, MD, PhD

Department of Genetics and Pathology

Rudbeck Laboratory, Uppsala University

SE-751-85 Uppsala, Sweden

Phone: +46 18 6115947; Fax: +46 18554025

e-mail: richard.rosenquist@genpat.uu.se 


\section{ABSTRACT}

Global hypomethylation and regional hypermethylation are well-known epigenetic features of cancer, however, in chronic lymphocytic leukemia (CLL), studies on genome-wide epigenetic modifications are limited. Here we analyzed the global methylation profiles in CLL, by applying high-resolution methylation micro-arrays (27,578 CpG sites) to $23 \mathrm{CLL}$ samples, belonging to the immunoglobulin heavy-chain variable (IGHV) mutated (favorable) and IGHV unmutated/IGHV3-21 (poor-prognostic) subsets. Overall, results demonstrated significant differences in methylation patterns between these subgroups. Specifically, in IGHV unmutated CLL, we identified methylation of 7 known or candidate tumor suppressor genes (e.g. $V H L, A B I 3$ and IGSF4) as well as 8 unmethylated genes involved in cell proliferation and tumor progression (e.g. ADORA3 and PRF1 enhancing the NF- $\kappa \mathrm{B}$ and MAPKinase pathways, respectively). In contrast, these latter genes were silenced by methylation in IGHV mutated patients. The array data was validated for selected genes using methylation-specific PCR, quantitative RT-PCR and bi-sulfite sequencing. Finally, the significance of DNA methylation in regulating gene promoters was shown by re-inducing 4 methylated tumor suppressor genes (e.g. $V H L$ and $A B I 3$ ) in IGHV unmutated samples using the methyl-inhibitor 5-aza-2'-deoxycytidine. Taken together, our data for the first time reveal differences in global methylation profiles between prognostic subsets of CLL, which may unfold epigenetic silencing mechanisms involved in CLL pathogenesis.

Key words: DNA methylation, micro-array, chronic lymphocytic leukemia, IGHV mutation status, IGHV3-21 usage. 


\section{INTRODUCTION}

Chronic lymphocytic leukemia (CLL) is characterized by clonal proliferation and accumulation of long-lived neoplastic B-cells, which arise due to altered control of apoptosis as well as proliferation. No common disease causing mutation has yet been identified in CLL, although certain recurrent genomic aberrations (i.e. 11q-, +12, 13q-, $17 \mathrm{p}-)$ provide important prognostic information. ${ }^{1}$ Besides these aberrations, the mutation status of the immunoglobulin heavy-chain variable (IGHV) genes segregates patients into two main prognostic subgroups, where patients with unmutated IGHV genes show inferior outcome compared to those with mutated IGHV genes. ${ }^{2,3}$ In addition, CLL patients utilizing the IGHV3-21 gene display poor outcome independent of mutation status. ${ }^{4}$

Aberrant DNA methylation has been shown to play a strong role in tumorogenesis, where genome-wide hypomethylation and regional hypermethylation of tumor suppressor gene promoters are characteristic hallmarks of many cancers. ${ }^{5}$ In CLL, the epigenetic mechanism of gene regulation has thus far received limited attention. That notwithstanding, a strong correlation between promoter methylation and transcriptional silencing was shown for certain individual gene promoters in CLL, for example, DAPK1 TWIST2, ZAP70 and HoxA4. ${ }^{6-9}$ The methylation status of several of these genes has also been reported to correlate with IGHV mutational status. To date, only one study has been performed using genome-wide methylation analysis in CLL using the 'Restriction Landmark Genomic Scanning' technique. They observed that $2-8 \%$ of $\mathrm{CpG}$ islands were aberrantly methylated compared to normal controls and that methylation events showed a

non-random distribution. ${ }^{10}$ However, this technique spans only $3000 \mathrm{CpG}$ islands and does not give a full coverage of the genome.

The main aim of this present investigation was to study and compare the genome-wide methylation profiles of different CLL prognostic subgroups to identify differentially 
methylated genes that can play a role in CLL pathogenesis. Recent studies have revealed that DNA hypermethylation in cancer is not always restricted to discrete $\mathrm{CpG}$ islands or single genes but can affect multiple adjacent $\mathrm{CpG}$ rich regions resulting in gene silencing across large genomic distances. ${ }^{11}$ Unlike promoter $\mathrm{CpG}$ island methylation arrays that cover sites near the promoter region, we here applied an Illumina Infinium HumanMethylation27 array (27,578 methylated sites, covering 14,495 genes) to 23 CLL patient samples belonging to the IGHV mutated, IGHV unmutated and IGHV3-21 CLL subgroups. We identified distinct methylation profiles between different subgroups and the array data was validated for selected genes using methylation-specific PCR (MSP-PCR), real-time quantitative PCR (RQ-PCR) and bi-sulfite sequencing. Finally, methylated genes were also re-expressed in CLL patient samples using methyl inhibitors to ascertain the role of DNA methylation in regulating gene expression.

\section{MATERIALS AND METHODS}

\section{Patient samples and Clinical data}

In this study, 23 tumor samples from patients with CLL (6 IGHV mutated, 7 IGHV unmutated and 10 IGHV3-21) were collected from the Biobank at the Department of Pathology, Uppsala University Hospital, Sweden. All samples were diagnosed according to recently revised criteria, ${ }^{12}$ showing typical CLL immunophenotype and $\geq 70 \%$ tumor cells. Clinical and molecular characteristics including IGHV mutation status and genomic aberrations are summarized in Table 1. Two normal healthy control samples (1 sample with peripheral blood mononuclear cells (PBMC) and 1 sample with CD19 sorted B-cells) and 1 negative control (whole-genome amplified DNA) were included for analysis. Additionally, 2 CLL EBV transformed cell lines (I83 derived from a mutated CLL patient and HG3 derived from an unmutated CLL patient) were included for analysis. Finally, 10 
additional CLL samples (5 IGHV mutated and 5 IGHV unmutated) were included in the validation experiments using MSP-PCR and another 50 CLL samples (27 IGHV mutated and 23 IGHV unmutated) were included in RQ-PCR analysis. None of these 60 latter samples were included in methylation array analysis. Informed consent was obtained according to the Declaration of Helsinki and the study was approved by the local ethical review committee.

\section{Methylation array analysis}

We applied the genome-wide Illumina Infinium HumanMethylation27 BeadChip array (Illumina, San Diego, USA) which allows interrogation of 27,578 CpG dinucleotides, covering 14,495 genes. First, bi-sulfite conversion of genomic DNA was performed using the EZ DNA Methylation Kit (Zymo Research, Orange, CA, USA) according to the manufacturer's protocol. Briefly, $1 \mu \mathrm{g}$ of DNA was sodium bisulfite treated, denatured at $95^{\circ} \mathrm{C}$ for 30 seconds, and bisulfite converted at $50^{\circ} \mathrm{C}$ for 12 hours. Following conversion, samples were desulphonated and eluted using column preparation. Approximately 100-125 ng of bi-sulfite converted DNA was processed according to the Illumina Infinium Methylation Assay protocol. This assay is based on the conversion of unmethylated Cnucleotides into $\mathrm{U}(\mathrm{T})$-nucleotides by the bisulfite treatment. The DNA was wholegenome amplified, enzymatically fragmented, precipitated, resuspended and hybridized over night at $48^{\circ} \mathrm{C}$ to locus specific oligonucleotide primers on the BeadArray. Following hybridization, the $\mathrm{C}$ or $\mathrm{T}$ nucleotides were detected by single base primer extension. The fluorescence signals corresponding to the $\mathrm{C}$ or $\mathrm{T}$ nucleotides were measured from the BeadArrays using an Illumina BeadStation GX scanner. The fluorescence data was then analyzed using the BeadStudio software (Illumina, San Diego, USA), which assigns a quantitative measure of the methylation levels (Beta-value or methylation index (MI) 
value) for each $\mathrm{CpG}$ site, that corresponds to the ratio between the fluorescence signal from the methylated allele $(\mathrm{C})$ and the sum of the fluorescent signals of the methylated (C) and unmethylated (T) alleles. The methylation status for each detected $\mathrm{CpG}$ site ranged between 0.1 (completely unmethylated) to 1 (completely methylated). MI cut-offs of $\geq 0.7$ and $\leq 0.4$ (average of all MI values in each group) were considered methylated and unmethylated, respectively.

Further bioinformatic analysis of the methylation data was carried out in the freely available statistical computing language R (http://www.r-project.org). In order to search for the differentially methylated genes between the different prognostic subgroups (i.e. IGHV mutated/unmutated and IGHV3-21 CLL patients) the data was arcsin transformed and an empirical Bayes moderated t-test was then applied using the 'limma' package. The p-values were adjusted using the method of Benjamini and Hochberg ${ }^{13}$ and a level of $\mathrm{p}<0.05$ was used as a cutoff. To identify differentially methylated genes of largest difference between subgroups an additional filter incorporating the average geometric difference was applied to ensure only genes with large absolute differences remained. Consequently, an average difference in MI of 0.45 between the IGHV mutated and IGHV unmutated subgroups, 0.35 between the IGHV3-21 and IGHV mutated subgroups and 0.35 between IGHV3-21 and IGHV unmutated subgroups was applied.

\section{Methylation-specific PCR analysis}

To verify the findings from the methylation arrays, we selected 4 genes for MSP-PCR. Methylated specific primers (MSP) were designed according to MSP primer selection criteria as outlined by Li and Dahiya. ${ }^{14}$ Specifically, sequences covering approximately 250bp flanking the identified CpG sites on either side were used for primer design in the Methprimer software (Bisearch, San Francisco, USA). The unmethylated-specific primers 
(USP) were designed around 50bp upstream and downstream of the methylation specific primers, as to cover the same $\mathrm{CpG}$ sites as those contained by the MSP region. Both MSP and USP primers are listed in Supplemental Table 1. The PCR reactions contained $1.5 \mathrm{mM}$ $\mathrm{MgCl}_{2}, 200 \mu \mathrm{M}$ dNTP mix (Invitrogen, Carlsbad, CA, USA), $0.2 \mu \mathrm{M}$ primers (Sigma Aldrich, St. Louis, MO), 1x PCR AmpliTaq gold buffer, 1.25U AmpliTaq Gold (Applied Biosystems, Carlsbad, CA, USA), 5\% DMSO (Merck, NJ, USA) and 50ng of bisulfitetreated DNA. The PCR reaction was performed as follows: denaturation at $95{ }^{\circ} \mathrm{C}$ for 10 minutes; 35 cycles of $94{ }^{\circ} \mathrm{C}$ for 45 seconds, $58^{\circ} \mathrm{C}$ for 45 seconds, $72{ }^{\circ} \mathrm{C}$ for 45 seconds and a final extension step of $72^{\circ} \mathrm{C}$ for 5 minutes. The PCR products were visualized on $2 \%$ agarose gels containing ethidium bromide.

\section{Real-time quantitative RT-PCR analysis}

To further analyze if methylation status influences the gene expression of specific genes, we selected 4 genes for RQ-PCR. Total RNA was extracted using RNA extraction Kit (Qiagen, Dusseldorf, Germany) according to the manufacturer's protocol. Reverse transcription reaction was performed using MMLV-RT kit (Invitrogen, Carlsbad, CA) and random hexamers (Fermentas, Burlington, Canada) according to the manufacturer's protocol. RT-PCR primers were designed using the Primer3 software (Broad institute, Boston, USA). All primer sequences are listed in Supplemental Table 1. Quantitative RTPCR analysis was performed using $2 \mathrm{X}$ SYBR green master mix according to manufacturer's protocol (Fermentas, Burlington, Canada). Expression was analyzed using the Stratagene Mx 3005p (Stratagene, La Jolla, CA, USA) detection system and calculated with the Max Pro QPCR software (Stratagene) using beta-actin as a reference gene and the $\Delta \Delta \mathrm{Ct}$ method. The statistical significance of differences in expression was calculated by a 
t-test and represented in box plot graphs using the Statistica 8.0 software (Stat Soft, Tulsa, OK).

\section{Bi-sulfite sequencing}

To confirm the methylation status of individual genes, we selected 2 genes for bi-sulfite sequencing. Bi-sulfite sequencing primers (BSP) were designed according to BSP primer selection criteria as outlined by $\mathrm{Li}$ and Dahiya $^{14}$ (Supplemental Table 1). PCR was performed using $1.5 \mathrm{mM} \mathrm{MgCl}_{2}, 200 \mu \mathrm{M}$ dNTP mix, $0.2 \mu \mathrm{M}$ primers (Sigma Aldrich, St. Louis, MO), 1x PCR Taq buffer, 1U Platinum Taq (Invitrogen, Carlsbad, CA, USA), and 50 ng of bi-sulfite-treated DNA. Touchdown PCR cycling conditions included 5 cycles at $95^{\circ} \mathrm{C}$ for 30 seconds, $55^{\circ} \mathrm{C}$ for 45 seconds and $72^{\circ} \mathrm{C}$ for 1 minute, followed by 5 cycles at $95^{\circ} \mathrm{C}$ for 30 seconds, $53^{\circ} \mathrm{C}$ for 45 seconds and $72^{\circ} \mathrm{C}$ for 1 minute, and a further 30 cycles at $94{ }^{\circ} \mathrm{C}$ for 30 seconds, $50^{\circ} \mathrm{C}$ for 45 seconds and $72{ }^{\circ} \mathrm{C}$ for 45 seconds, followed by a final extension step of $72^{\circ} \mathrm{C}$ for 5 minutes. The PCR product was cloned using the Invitrogen TOPO TA cloning kit-2.1 TOPO vector (Invitrogen, Carlsbad, CA, USA), and 10-12 clones per sample were selected for verification of the correct sized insert via PCR using vector specific M13 forward and reverse primers (provided by the cloning kit). Verified PCR products were treated using 0.5 U Exo I and 1.0 U SAP (Fermentas, Burlington, Canada) at $37^{\circ} \mathrm{C}$ for 45 minutes and $80^{\circ} \mathrm{C}$ for 15 minutes and sequenced with vector specific primers using the BigDye Terminator Cycle Sequencing Reaction Kit (PerkinElmer, Foster City, CA). All sequence reactions were analyzed using an automated DNA sequencer (ABI 377, Applied Biosystems, Foster City, CA). Sequences were aligned and analyzed using the bisulfite sequencing web-based tool BiQ Analyzer software (MaxPlanck Institut fur informatik, Saarbrucken, Germany) and the degree of methylation represented as a lolli-pop grid. 


\section{5-aza-2'-deoxycytidine (DAC) and Trichostatin A (TSA) treatment}

Frozen primary CLL cell samples and the CLL cell line HG3 were cultured in RPMI-1640 media supplemented with 10\% FBS (Sigma Aldrich, St. Louis, MO) 4mM glutamine and $1 \mathrm{X}$ penicillin/streptomycin (Invitrogen, Carlsbad, CA, USA) until confluent. Cells were then subdivided to contain $\sim 1$ million cells $/ \mathrm{ml} /$ well 12 hours before treatment, to allow the cells to adjust to conditions. Cells were subsequently cultured over 3 days in supplemented RPMI media treated with one of the following treatments: 1) medium containing 5-aza-2'deoxycytidine (DAC) $(5 \mu \mathrm{M} / \mathrm{L}$, Sigma Aldrich, St. Louis, MO) for 72 hours whereby medium was changed every 24 hours, 2) medium containing Trichostatin A (TSA) (500nM/lit, Sigma Aldrich, St. Louis, MO) for the last 24 hours, and 3) medium containing DAC for $48 \mathrm{hrs}$ followed by addition of TSA for $24 \mathrm{hrs}$. Control cells were cultured in similar way with no drugs added.

\section{RESULTS}

\section{Distribution of samples based on overall methylation index}

This study investigated a total of 27 samples, encompassing 6 IGHV mutated, 7 IGHV unmutated, and 10 IGHV3-21 CLL patient samples, as well as 2 healthy control samples (1 obtained from PBMC and 1 from sorted B-cells), 2 EBV transformed CLL cell lines and 1 negative control (whole-genome amplified DNA). Figure 1 graphically represents the MI values obtained from all samples. As expected the negative control sample showed lowest MI, and the healthy control samples displayed the highest values. All CLL patient samples fell in the range between these controls, whereas the two CLL cell lines displayed lower MIs when compared to the CLL samples. Hence, healthy controls had a higher degree of genome-wide methylation, whereas the CLL cell lines showed less methylation compared to the CLL patient samples. 


\section{Methylation profiling of different prognostic subgroups of CLL}

Genome-wide methylation profiles were compared between samples from three different CLL subgroups, i.e. IGHV mutated, IGHV unmutated and IGHV3-21 CLL. Additionally, healthy controls were included for comparison. Since the CLL cell lines showed completely different methylation profiles as compared to CLL patient samples, these were not included in the comparisons. Using highly stringent selection criteria (as detailed in Materials and Methods), a total of 64 genes were identified as significantly differentially methylated between IGHV mutated and unmutated CLL (Figure 2A). Similarly, 60 and 31 genes were identified in the comparison between IGHV unmutated versus IGHV3-21 CLL and IGHV mutated versus IGHV3-21 CLL, respectively (Figure 2B-C). Based on the functionality of all these identified differentially methylated genes, they could be grouped into various categories, such as apoptotic related genes (anti-apoptotic or pro-apoptotic), known or candidate tumor suppressor genes, genes involved in high proliferative activity, genes enhancing tumorogenesis, drug resistance genes and genes associated with prognosis, as described in Table 2. Importantly, we identified known/candidate tumor suppressor genes that were preferentially methylated in the IGHV unmutated (7 genes, e.g. VHL, ABI3), IGHV3-21(1 gene, SLC22A18) and IGHV mutated (2 genes, PPPIR3A and WISP3) subgroups. We also identified 10 unmethylated and hence potentially expressed genes shown to be involved in activation of proliferative pathways such as the NFKB pathway (e.g. $A D O R A 3$ and $C A R D 15)$, and the MAP/ERK kinase pathway (e.g. PRF1 and FABP7) in the IGHV unmutated and IGHV3-21 subgroups. Of the identified genes, most have previously not been associated with CLL, however many were known to be involved in the tumorogenesis of several other cancers and leukemia. 


\section{Confirmation of array data using methylation-specific PCR and RQ-PCR}

To confirm the array data, we selected 4 genes for MSP-PCR, i.e. PRF1 and ADORA3 (methylated in IGHV mutated CLL samples), BCLIO and IGSF4 (methylated in IGHV unmutated CLL samples). PRF1 and ADORA3 are mainly involved in cell proliferation by

constitutive activation of the MAPK and NFкB pathways, respectively, ${ }^{15,16}$ whereas BCL10 is an anti-apoptotic gene ${ }^{17}$ and IGSF4 is a candidate tumor suppressor gene. ${ }^{18}$ Figure 3A illustrates the results for 3 IGHV mutated and 4 unmutated CLL samples, verifying that $P R F 1$ and $A D O R A 3$ were mostly methylated in mutated samples, whereas mostly BCL1O and IGSF4 were methylated in unmutated samples. Additionally, we selected 10 additional IGHV mutated and unmutated CLL samples (not included in the array study), and analyzed the methylation status for ADORA3 and BCL10, which further confirmed the divergent methylation status between the mutated/unmutated CLL subgroups (Figure 3B).

Following conformation of the methylation status of the selected genes, we correlated this data with mRNA expression levels of the respective genes as well as 3 additional genes (i.e. $V H L, A B I 3$ and $N G F R$ ) using RQ-PCR. Figure 4 demonstrates RQ-PCR results for 4 of the genes (VHL, ABI3, ADORA3 and BCL-10) in a CLL cohort of 50 samples, confirming that the mRNA expression levels correlated strongly with the methylation status. Of the 4 genes analyzed, 3 genes ( $V H L, A B I 3$ and $B C L-10)$ showed a significant difference between the IGHV mutated and unmutated subgroups. Furthermore, RT-PCR results for the PRF1 and NGFR genes (Supplemental Figure 1) were analyzed on the same 4 IGHV mutated and unmutated samples included in the MSP-PCR analyses, further verifying the MSP-PCR data. 


\section{Bi-sulfite sequencing of methylated tumor suppressor genes}

Two candidate tumor suppressor genes (VHL and $A B I 3)$ that displayed significant differences in gene expression levels between IGHV mutated and unmutated CLL samples were selected for bi-sulfite sequencing and subcloning to confirm the degree of methylation using 2 IGHV mutated and 2 IGHV unmutated samples. The bi-sulfite sequencing region covered the $\mathrm{CpG}$ sites which were included in the array and showed a significant difference in the MI values between IGHV mutated and IGHV unmutated samples. Both genes exhibited a high degree of hypermethylation in the IGHV unmutated samples compared to the IGHV mutated samples (Figure 5).

\section{Re-expression of methylated genes using a methyl inhibitor}

To investigate the role of DNA methylation in transcriptional regulation of gene promoters, we examined the effects of DNA methyl transferase inhibitor 5-aza-2'deoxycytidine (DAC) and/or histone deacetylase inhibitor trichostatin A (TSA) treatment on gene expression in 3 IGHV unmutated and 3 IGHV mutated CLL samples. Four genes found to be mainly hypermethylated in unmutated samples (IGSF4, VHL, ABI3 and NGFR) were selected for re-expression analysis. An increase in the activation of the IGSF4, $A B I 3$ and VHL genes was observed in response to DAC or TSA treatment, especially when applied in combination, in several of the IGHV unmutated CLL samples as compared to the corresponding untreated samples (Figure 6). Reactivation of the NGFR gene is shown in Supplemental Figure 2. Similar data was obtained for all the above mentioned genes using the CLL EBV transformed cell line HG3 (data not shown). 


\section{DISCUSSION}

In hematological malignancies, genes involved in important cellular pathways have been described to be affected by $\mathrm{CpG}$ island methylation in association with transcriptional silencing. ${ }^{19}$ The role of aberrant DNA methylation and individual DNA promoter methylation has been investigated in CLL (e.g. ZAP-70, TWIST 2) ${ }^{6,7}$, although there have been few comprehensive studies dedicated to uncover the methylation status on a global level. Using a genome-wide methylation array, we here for the first time identified distinct methylation profiles in prognostic subsets of CLL.

In tumor cells, a disrupted methylation pattern is often observed featuring global hypomethylation and region-specific hypermethylation of certain gene promoters, compared to their normal cellular counterparts. In the present study the overall degree of methylation, indicated as MI values, of all CLL primary samples demonstrated lower methylation levels compared to normal healthy controls (Figure 1), which is in line with previous findings. ${ }^{20} \mathrm{We}$ also noticed that the EBV-transformed CLL cell lines displayed very different methylation patterns compared to CLL primary samples with lower MI values. This is perhaps not unexpected considering their higher proliferative capacity.

To identify differentially methylated genes between CLL subgroups we applied a stringent bioinformatic approach which revealed significantly different methylation profiles between IGHV unmutated and mutated CLL as well as between IGHV mutated/unmutated and IGHV3-21 CLL (Figure 2). Many of the identified genes were found to be involved in important cellular pathways, where dysregulation of these genes could significantly contribute to leukemogenesis. For instance, we identified known or candidate tumor suppressor genes that were preferentially methylated in the poorprognostic IGHV unmutated (7 genes) and IGHV3-21 (1 gene) subgroups (Table 2). Although many of these genes have been implicated in several other cancers (Table 2), 
their role in CLL has not been investigated. Some of the known or candidate tumor suppressor genes that were specifically methylated in IGHV unmutated CLL were: ABI3, implicated in lung metastasis ${ }^{21}, V H L$, mutated in sporadic renal cell carcinoma as well as in the hereditary syndrome von Hippel-Lindau ${ }^{22}$ and IGSF4, methylated in neuroblastoma ${ }^{18}$. Furthermore, we performed validation experiments to verify the methylation data from the arrays. For instance, the high degree of methylation and the corresponding decreased gene expression of 2 genes, $V H L$ and $A B I 3$, were confirmed by both bi-sulfite sequencing and RQ-PCR in IGHV unmutated CLL (Figure 4 and 5). Taken together, several tumor suppressor genes were found methylated particularly in poor-prognostic, unmutated CLL, while they remained unmethylated and hence expressed in IGHV mutated CLL.

Previous studies implicate that certain cellular pathways, such as NFאB, PI3K/Akt and MEK/ERK, are dysregulated in CLL B-cells leading to activation of anti-apoptotic pathways. Our data strengthens this idea and further indicates that certain genes involved in such 'proliferative' pathways may be controlled by DNA methylation in CLL. In particular, we identified expression of genes that enhance constant cell proliferation and invasion in the IGHV unmutated CLL subgroup (Table 2). Some of the genes included were ADORA3 and PRF1 genes, that activate the NFKB and MAPKinase pathways, respectively, and which were expressed in the poor-prognostic CLL subsets compared to IGHV mutated CLL. ${ }^{16,23}$ Also, genes involved in repressing the NFkB pathway (LCODI gene $)^{28}$ and MAPKinase (ZNF540 gene $)^{29}$ pathways were generally methylated in both IGHV unmutated and IGHV3-21 samples in contrast to IGHV mutated CLL. The methylation status and gene expression were confirmed for two such genes, e.g. ADORA3 and PRF1 using both MS-PCR and RQ-PCR in IGHV unmutated versus mutated CLL (Figure 3 and 4). Moreover, genes previously reported to be involved in facilitating tumorogenesis within other cancer types were noted to be preferentially unmethylated in 
the IGHV unmutated (7 genes) and IGHV3-21 (4 genes) CLL subgroups in comparison to IGHV mutated CLL (Table 2). For example, IFNB1, shown to enhance B-cell proliferation, ${ }^{24}$ and $I L 17 R C$, involved in facilitating tumorogenesis in prostate cancer, ${ }^{25}$ were unmethylated in IGHV unmutated samples. Thus, the above data indicates that poorprognostic CLL subsets favor expression of genes aiding tumor proliferation.

In contrast to IGHV unmutated CLL, IGHV mutated CLL showed mainly deregulation of anti- and pro-apoptotic genes. In particular, BCL2, a known anti-apoptotic gene, ${ }^{26}$ remained unmethylated in IGHV mutated CLL samples. On the other hand, pro-apoptotic genes such as $B C L 10^{17}$ and TP5313 shown to induce p53-mediated cell death, ${ }^{27}$ were methylated in IGHV mutated samples unlike IGHV unmutated CLL. As shown in Figure 3, we could confirm both the differential methylation status and expression level of BCL1O in mutated and unmutated CLL.

Interestingly, we also identified certain genes that have been related to prognosis, for instance, the ANGPT2 gene which has been shown to be expressed preferentially in IGHV unmutated CLL samples. ${ }^{28}$ Our array data indeed demonstrated that this gene was methylated in mutated CLL while being unmethylated in unmutated CLL. In addition, expression of the $N G F R$ gene, which has been associated with favorable prognosis in ALL, ${ }^{29}$ was unmethylated in IGHV mutated CLL and showed increased expression on the RNA level within this subset (Supplemental Figure 1). However, further analysis of the ANGPT2 and NGFR genes in a larger CLL cohort is needed to assess their prognostic impact. .

Apart from the 'traditional' genes, the HumanMethylation27 BeadChip array also contains 110 miRNA promoters. However, none of these miRNAs met the criteria set to define a significant difference in methylation between the studied subsets. Evidently, this 
does not exclude that methylation changes may exist between CLL subsets considering that only a fraction of miRNA promoters were covered by the array.

Unlike genetic changes, epigenetic changes are reversible using de-methylating agents such as 5-aza-deoxycytidine (DAC). Consequently, the role of these agents as treatment options is currently under investigation in hematological malignancies including CLL. ${ }^{33,34}$ In this study, we demonstrated that inhibition of DNA methylation using methyl- and HDAC inhibitors could induce expression of methylated tumor suppressor genes (e.g. IGSF4, $A B I 3$ and $V H L$ ) in unmutated CLL primary samples. We generally did not observe high induction of gene expression with methyl inhibitor treatment, probably due to the fact that CLL primary cells do not proliferate at a high rate under in vitro conditions, although the effect of the drugs was pronounced when applied in combination. These data indeed strengthen the role of DNA methylation in regulating promoter expression and open up the possibility of targeted therapy, although this has to be studied further.

Gene expression micro-array studies have previously revealed different gene expression profiles between IGHV mutated and IGHV unmutated/IGHV3-21 CLL patients. ${ }^{30-32}$ However, the vast majority of the identified genes in the present study could not be found in these gene expression studies. ${ }^{30-32}$ There could be several possible explanations for this, for example, incomplete overlap with genes included on the expression arrays, and different criteria applied for identifying genes differing between subsets. Gene expression can also be silenced by other mechanisms than methylation, for instance mutations or deletions, which will not be identified on methylation arrays. Also, we cannot exclude the possibility that differentially methylated genes may not always correlate with a significant difference in gene expression. Since this is one of the first studies using the whole-genome Illumina array, we decided to apply stringent criteria in order to reduce false positive genes. On the other hand, we may indeed have lost some 
important genes, which would have come up using less stringent criteria. That notwithstanding, we believe that our confirmation experiments using different techniques such as MSP-PCR, RQ-PCR and bi-sulfite sequencing strengthen the validity of our data.

In conclusion, the observation that the distinct methylation profiles encompassed candidate genes involved in cellular pathways regulating proliferation and apoptosis in IGHV unmutated and mutated CLL underlines a critical role for epigenetic changes during leukemogenesis. Most identified tumor suppressor genes were specifically silenced in IGHV unmutated CLL, implicating the role of these genes in the pathogenesis of this subgroup. Specific inhibition of expression of unmethylated genes involved in facilitating tumorogenesis and re-expression of methylated candidate tumor suppressor genes within the poor-prognostic subgroups could represent a possible route for drug therapy. Hopefully, our results may help to further unravel the pathogenesis of CLL and identify possible novel biomarkers and targets for drug therapy in CLL.

\section{ACKNOWLEDGEMENTS}

This work was supported by the Swedish Cancer Society, the Swedish Research Council, the Medical Faculty of Uppsala University, Uppsala University Hospital, and Lion's Cancer Research Foundation in Uppsala, Sweden. ABBEST, Ireland, provided a stipend for NC.

\section{AUTHOR CONTRIBUTION/DISCLOSURES}

MK and NC performed research, analyzed data and wrote the paper; HG and AI performed bioinformatic analyses and analyzed data; CE performed micro-array analysis and analyzed data; FR analyzed data, R.R. supervised the research and wrote the paper. The authors have no disclosures. 


\section{REFERENCES}

1. Döhner H, Stilgenbauer S, Benner A, et al. Genomic Aberrations and Survival in Chronic Lymphocytic Leukemia. N Engl J Med. 2000;343 (26):1910-1916.

2. Hamblin TJ, Davis Z, Gardiner A, Oscier DG, Stevenson FK. Unmutated Ig VH Genes Are Associated With a More Aggressive Form of Chronic Lymphocytic Leukemia. Blood. 1999;94 (6):1848-1854.

3. Damle RN, Wasil T, Fais F, et al. Ig V Gene Mutation Status and CD38 Expression As Novel Prognostic Indicators in Chronic Lymphocytic Leukemia. Blood. 1999;94 (6):1840-1847.

4. Thorselius M, Kröber A, Murray F, et al. Strikingly homologous immunoglobulin gene rearrangements and poor outcome in VH3-21-using chronic lymphocytic leukemia patients independent of geographic origin and mutational status. Blood. 2006;107 (7):2889-2894.

5. Eden A, Gaudet F, Waghmare A, Jaenisch R. Chromosomal instability and tumors promoted by DNA hypomethylation. Science. 2003;300 (5618):455.

6. Corcoran M, Parker A, Orchard J, et al. ZAP-70 methylation status is associated with ZAP-70 expression status in chronic lymphocytic leukemia. Haematologica. 2005;90 (8):1078-1088.

7. Raval A, Lucas DM, Matkovic JJ, et al. TWIST2 demonstrates differential methylation in immunoglobulin variable heavy chain mutated and unmutated chronic lymphocytic leukemia. J Clin Oncol. 2005;23 (17):3877-3885.

8. Strathdee G, Sim A, Parker A, Oscier D, Brown R. Promoter hypermethylation silences expression of the HoxA4 gene and correlates with $\mathrm{IgVh}$ mutational status in CLL. Leukemia. 2006;20 (7):1326-1329.

9. Raval A, Tanner SM, Byrd JC, et al. Downregulation of Death-Associated Protein Kinase 1 (DAPK1) in Chronic Lymphocytic Leukemia. 2007;129 (5):879-890.

10. Rush LJ, Raval A, Funchain P, et al. Epigenetic Profiling in Chronic Lymphocytic Leukemia Reveals Novel Methylation Targets. Cancer Res. 2004;64 (7):24242433.

11. Frigola J, Song J, Stirzaker C, Hinshelwood RA, Peinado MA, Clark SJ. Epigenetic remodeling in colorectal cancer results in coordinate gene suppression across an entire chromosome band. Nat Genet. 2006;38 (5):540-549.

12. Hallek M, Cheson BD, Catovsky D, et al. Guidelines for the diagnosis and treatment of chronic lymphocytic leukemia: a report from the International Workshop on Chronic Lymphocytic Leukemia updating the National Cancer Institute-Working Group 1996 guidelines. Blood. 2008;111 (12):5446-5456.

13. Benjamini Y, Hochberg Y. Controlling the false discovery rate: a practical and powerful approach to multiple testing. Journal of the Royal Statistical Society. 1995;Series B (57):289-300.

14. Li L-C, Dahiya R. MethPrimer: designing primers for methylation PCRs. Bioinformatics. 2002;18 (11):1427-1431.

15. Bar-Yehuda S, Stemmer SM, Madi L, et al. The A3 adenosine receptor agonist CF102 induces apoptosis of hepatocellular carcinoma via de-regulation of the Wnt and NF-kappaB signal transduction pathways. Int J Oncol. 2008;33 (2):287-295.

16. Kathi Z, Heiko E, Regine K, Michael F. Pheromone-regulated target genes respond differentially to MAPK phosphorylation of transcription factor Prf1. Molecular Microbiology. 2008;69 (4):1041-1053.

17. Grimwade D, Du MQ, Langabeer S, Rogers J, Solomon E. Screening for mutations of Bcl10 in leukaemia. Br J Haematol. 2000;109 (3):611-615. 
18. Ando K, Ohira M, Ozaki T, et al. Expression of TSLC1, a candidate tumor suppressor gene mapped to chromosome 11q23, is downregulated in unfavorable neuroblastoma without promoter hypermethylation. Int J Cancer. 2008;123 (9):2087-2094.

19. Egger G, Liang G, Aparicio A, Jones PA. Epigenetics in human disease and prospects for epigenetic therapy. Nature. 2004;429 (6990):457-463.

20. Wahlfors J, Hiltunen H, Heinonen K, Hamalainen E, Alhonen L, Janne J. Genomic hypomethylation in human chronic lymphocytic leukemia. Blood. 1992;80 (8):2074-2080.

21. Matsuda S, Yokozaki S, Yoshida H, Kitagishi Y, Shirafuji N, Okumura N. Insulin receptor substrate protein 53 (IRSp53) as a binding partner of antimetastasis molecule NESH, a member of Abelson interactor protein family. Ann Oncol. 2008;19 (7):1356-1357.

22. Latif F, Tory K, Gnarra J, et al. Identification of the von Hippel-Lindau disease tumor suppressor gene. Science. 1993;260 (512):1317-1320.

23. Ishikawa H, Barber GN. STING is an endoplasmic reticulum adaptor that facilitates innate immune signalling. Nature. 2008;455 (7213):674-678.

24. Francois DT, Katona IM, June CH, Wahl LM, Mond JJ. Examination of the inhibitory and stimulatory effects of IFN-alpha, -beta, and -gamma on human Bcell proliferation induced by various B-cell mitogens. Clin Immunol Immunopathol. 1988;48 (3):297-306.

25. Haudenschild DR, Curtiss SB, Moseley TA, Reddi AH. Generation of interleukin17 receptor-like protein (IL-17RL) in prostate by alternative splicing of RNA. Prostate. 2006;66 (12):1268-1274.

26. Hockenbery D, Nunez G, Milliman C, Schreiber RD, Korsmeyer SJ. Bcl-2 is an inner mitochondrial membrane protein that blocks programmed cell death. Nature. 1990;348 (6299):334-336.

27. Contente A, Dittmer A, Koch MC, Roth J, Dobbelstein M. A polymorphic microsatellite that mediates induction of PIG3 by p53. Nat Genet. 2002;30 (3):315320.

28. Maffei R, Marasca R, Martinelli S, et al. Angiopoietin-2 expression in B-cell chronic lymphocytic leukemia: association with clinical outcome and immunoglobulin heavy-chain mutational status. Leukemia. 2007;21 (6):1312-1315.

29. Troeger A, Gudowius S, Escherich G, et al. High nerve growth factor receptor (p75NTR) expression is a favourable prognostic factor in paediatric B cell precursor-acute lymphoblastic leukaemia. Br J Haematol. 2007;139 (3):450-457.

30. Klein U, Tu Y, Stolovitzky GA, et al. Gene expression profiling of B cell chronic lymphocytic leukemia reveals a homogeneous phenotype related to memory B cells. J Exp Med. 2001;194 (11):1625-1638.

31. Rosenwald A, Alizadeh AA, Widhopf G, et al. Relation of gene expression phenotype to immunoglobulin mutation genotype in B cell chronic lymphocytic leukemia. J Exp Med. 2001;194 (11):1639-1647.

32. Fält S, Merup M, Tobin G, et al. Distinctive gene expression pattern in VH3-21 utilizing B-cell chronic lymphocytic leukemia. Blood. 2005;106 (2):681-689.

33. Issa JP, Byrd JC. Decitabine in chronic leukemias. Semin Hematol. 2005;42 (3):S43-49.

34. Claus R, Almstedt M, Lubbert M. Epigenetic treatment of hematopoietic malignancies: in vivo targets of demethylating agents. Semin Oncol. 2005;32 (5):511-520. 
35. Murray F, Darzentas N, Hadzidimitriou A, et al. Stereotyped patterns of somatic hypermutation in subsets of patients with chronic lymphocytic leukemia: implications for the role of antigen selection in leukemogenesis. Blood. 2008;111 (3):1524-1533.

36. Gunnarsson R, Staaf J, Jansson M, et al. Screening for copy-number alterations and loss of heterozygosity in chronic lymphocytic leukemia - A comparative study of four differently designed, high resolution microarray platforms. Genes, Chromosomes and Cancer. 2008;47 (8):697-711.

37. Sjodin A, Guo D, Sorhaug S, Bjermer L, Henriksson R, Hedman H. Dysregulated secretoglobin expression in human lung cancers. Lung Cancer. 2003;41 (1):49-56.

38. Hayashida Y, Goi T, Hirono Y, Katayama K, Urano T, Yamaguchi A. PPP1R3 gene (protein phosphatase 1) alterations in colorectal cancer and its relationship to metastasis. Oncol Rep. 2005;13 (6):1223-1227.

39. Kleer CG, Zhang Y, Pan Q, et al. WISP3 is a novel tumor suppressor gene of inflammatory breast cancer. Oncogene. 2002;21 (20):3172-3180.

40. Nagafuchi S, Katsuta H, Koyanagi-Katsuta R, et al. Autoimmune regulator (AIRE) gene is expressed in human activated CD4+ T-cells and regulated by mitogenactivated protein kinase pathway. Microbiol Immunol. 2006;50 (12):979-987.

41. Kanazawa N, Okafuji I, Kambe N, et al. Early-onset sarcoidosis and CARD15 mutations with constitutive nuclear factor-kappaB activation: common genetic etiology with Blau syndrome. Blood. 2005;105 (3):1195-1197.

42. Slipicevic A, Jorgensen K, Skrede M, et al. The fatty acid binding protein 7 (FABP7) is involved in proliferation and invasion of melanoma cells. BMC Cancer. 2008;8:276.

43. Zhang J, Xu LG, Han KJ, Shu HB. Identification of a ZU5 and death domaincontaining inhibitor of NF-kappaB. J Biol Chem. 2004;279 (17):17819-17825.

44. Boyd RS, Adam PJ, Patel S, et al. Proteomic analysis of the cell-surface membrane in chronic lymphocytic leukemia: identification of two novel proteins, BCNP1 and MIG2B. Leukemia. 2003;17 (8):1605-1612.

45. Jang YH, Namkoong S, Kim YM, Lee SJ, Park BJ, Min DS. Cleavage of phospholipase D1 by caspase promotes apoptosis via modulation of the p53dependent cell death pathway. Cell Death Differ. 2008;15 (15):1782-1793.

46. Dumoutier L, Leemans C, Lejeune D, Kotenko SV, Renauld JC. Cutting edge: STAT activation by IL-19, IL-20 and mda-7 through IL-20 receptor complexes of two types. J Immunol. 2001;167 (7):3545-3549.

47. Yu YP, Yu G, Tseng G, et al. Glutathione peroxidase 3, deleted or methylated in prostate cancer, suppresses prostate cancer growth and metastasis. Cancer Res. 2007;67 (17):8043-8050.

48. Maass N, Hojo T, Zhang M, Sager R, Jonat W, Nagasaki K. Maspin--a novel protease inhibitor with tumor-suppressing activity in breast cancer. Acta Oncol. 2000;39 (8):931-934.

49. Yamada HY, Gorbsky GJ. Tumor suppressor candidate TSSC5 is regulated by UbcH6 and a novel ubiquitin ligase RING105. Oncogene. 2006;25 (9):1330-1339.

50. Nagasaki K, Schem C, von Kaisenberg C, et al. Leucine-zipper protein, LDOC1, inhibits NF-kappaB activation and sensitizes pancreatic cancer cells to apoptosis. Int J Cancer. 2003;105 (4):454-458.

51. Xiang Z, Yuan W, Luo N, et al. A novel human zinc finger protein ZNF540 interacts with MVP and inhibits transcriptional activities of the ERK signal pathway. Biochem Biophys Res Commun. 2006;347 (1):288-296. 
52. Coughlin JJ, Stang SL, Dower NA, Stone JC. RasGRP1 and RasGRP3 regulate B cell proliferation by facilitating B cell receptor-Ras signaling. J Immunol. 2005;175 (11):7179-7184.

53. Natkunam Y, Zhao S, Mason DY, et al. The oncoprotein LMO2 is expressed in normal germinal-center B cells and in human B-cell lymphomas. Blood. 2007;109 (4):1636-1642.

54. McGraw TP, Folds JD, Bollum FJ, Stass SA. Terminal deoxynucleotidyl transferase-positive acute myeloblastic leukemia. Am J Hematol. 1981;10 (3):251258. 


\begin{tabular}{|c|c|c|c|c|c|c|c|}
\hline CLL sample & $\begin{array}{l}\text { Percent } \\
\text { identity }^{\mathrm{a}}\end{array}$ & $\begin{array}{c}\text { Age at } \\
\text { diagnosis } \\
\text { (years) }\end{array}$ & Gender & $\begin{array}{l}\text { Survival } \\
\text { (months) }^{\text {b }}\end{array}$ & $\begin{array}{l}\text { Binet } \\
\text { stage }\end{array}$ & $\begin{array}{c}\text { Treated } \\
\text { before } \\
\text { sampling }\end{array}$ & $\begin{array}{l}\text { Genomic } \\
\text { aberrations }^{d}\end{array}$ \\
\hline \multicolumn{8}{|l|}{ IGHV mutated } \\
\hline M1 & 94.6 & 63 & M & $195+$ & A & No & $\operatorname{del}(13 q)^{3}$ \\
\hline M2 & 91.5 & 74 & M & 55 & A & No & $\operatorname{del}(13 q)^{1}$ \\
\hline M3* & 93.2 & 72 & M & $129+$ & A & ND & None $^{3}$ \\
\hline M4 & 94.1 & 70 & M & $134+$ & A & No & $\operatorname{del}(13 q)^{3}$ \\
\hline M5 & 91.3 & 65 & M & $104+$ & A & No & $\operatorname{del}(13 q)^{1}$ \\
\hline M6 & 91.1 & 64 & $\mathrm{~F}$ & $94+$ & A & No & None $^{3}$ \\
\hline \multicolumn{8}{|c|}{ IGHV unmutated } \\
\hline UM1 & 100.0 & 49 & M & 99 & A & Yes & $\operatorname{del}(11 q)^{3}$ \\
\hline UM2 & 100.0 & 44 & M & 84 & B & ND & $\operatorname{del}(11 q)^{3}$ \\
\hline UM3 & 100.0 & 79 & M & 10 & B & No & ND \\
\hline UM4 & 100.0 & 82 & $\mathrm{~F}$ & 50 & B & No & ND \\
\hline UM5 & 100.0 & 57 & M & 49 & B & No & $\operatorname{del}(13 q)^{1}$ \\
\hline UM6 & 100.0 & 69 & M & 24 & $\mathrm{C}$ & No & None $^{3}$ \\
\hline UM7 & 100.0 & 51 & M & $112+$ & A & No & None $^{1}$ \\
\hline \multicolumn{8}{|l|}{ IGHV3-21 } \\
\hline 3-21-1 & 100.0 & 45 & $\mathrm{~F}$ & 58 & ND & ND & $+12^{2}$ \\
\hline $3-21-2$ & 100.0 & 63 & M & 58 & $\mathrm{C}$ & No & $\operatorname{del}(13 q), \operatorname{del}(11 q)^{1}$ \\
\hline $3-21-3$ & $96.50^{\#}$ & 61 & M & 52 & $\mathrm{C}$ & No & $\operatorname{del}(13 q), \operatorname{del}(11 q)^{1}$ \\
\hline $3-21-4$ & $96.9^{\#}$ & 62 & $\mathrm{~F}$ & 67 & ND & No & $\operatorname{del}(13 q)^{2}$ \\
\hline $3-21-5$ & 100.0 & 65 & $\mathrm{~F}$ & 52 & ND & Yes & $\operatorname{del}(17 p),+12^{1}$ \\
\hline $3-21-6$ & $98.7^{\#}$ & 67 & M & ND & ND & ND & $\operatorname{del}(13 q), \operatorname{del}(11 q)^{1}$ \\
\hline $3-21-7$ & $96.49^{\#}$ & 63 & M & ND & ND & ND & $\operatorname{del}(13 q)^{3}$ \\
\hline $3-21-8$ & $95.5^{\#}$ & 60 & M & 72 & B & No & None $^{1}$ \\
\hline $3-21-9$ & $96.8^{\#}$ & 62 & M & 111 & ND & ND & $\operatorname{del}(13 q)^{2}$ \\
\hline $3-21-10$ & $97.4^{\#}$ & 76 & $\mathrm{M}$ & 82 & A & No & $\operatorname{del}(13 q), \operatorname{del}(11 q)^{2}$ \\
\hline
\end{tabular}

Table 1. Clinical and molecular data for the CLL patients included.

${ }^{\text {a }}$ IGHV gene analysis was performed using PCR amplification and nucleotide sequencing as previously described.$^{35}$ Cases with $\geq 98 \%$ identity to germline were classified as unmutated, whereas cases with $<98 \%$ identity were considered mutated. IGHV3-21 cases were classified as stereotyped (\#) or non-stereotyped according to Murray et al. ${ }^{35}$

${ }^{\mathrm{b}}$ Months from diagnosis to last observation or death.(+) indicates that the patient is alive.

${ }^{\mathrm{c}}$ Denotes treatment status before sampling, (yes) indicates that the patient was treated before sampling, whereas (no) indicates that the patient remained untreated.

${ }^{d}$ Known recurrent aberrations, i.e. $\operatorname{del}(13 q), \operatorname{del}(11 q), \operatorname{del}(17 p)$ and trisomy 12, were determined using FISH analysis (1), SNP-array analysis (2) or quantitative PCR analysis (3). FISH analysis was performed using commercially available probes as decribed previously, ${ }^{36}$ whereas SNP array analysis was performed using highresolution Affymetrix 250K SNP-arrays from which data on known recurrent genomic aberrations were extracted. ${ }^{36}$ Quantitative PCR was performed by applying specifically designed primers for each locus (primers available on request) using the SYBR green master mix according to the manufacturer's protocol (Fermentas, Burlington, Canada). Copy-number changes were normalized against a copy-number neutral internal control region and ratios relative to the DNA copy-number from a pooled control (Promega, Madison) were tallied for each locus.

* A second mutated, in-frame IGHV gene rearrangement (92\% identity) was also detected in this case.

ND, not defined. 
Table 2. Functional characterization of selected differentially methylated genes.

\begin{tabular}{|c|c|c|c|c|c|c|}
\hline $\begin{array}{c}\text { Functionality of } \\
\text { genes }\end{array}$ & $\begin{array}{l}\text { Gene } \\
\text { names }\end{array}$ & $\begin{array}{l}\text { IGHV } \\
\text { mutated }\end{array}$ & $\begin{array}{l}\text { IGHV } \\
\text { unmutated }\end{array}$ & Implicated role in cancer & $\begin{array}{l}\text { Accession } \\
\text { number }\end{array}$ & Ref \\
\hline \multirow{5}{*}{$\begin{array}{c}\text { Tumor } \\
\text { suppressor genes }\end{array}$} & $A B I 3^{*}$ & Unmethylated & Methylated & Lost in cancer cell lines, implicated in lung metastasis & NM_016428.3 & 21 \\
\hline & $S C G B 2 A 1^{*}$ & Unmethylated & Methylated & Methylated in lung cancer & NM_002407.1 & 37 \\
\hline & $V H L$ & Unmethylated & Methylated & Mutated in sporadic cell renal carcinoma and von Hippel-Lindau syndrome & NT_022517.17 & 22 \\
\hline & $P P P 1 R 3 A^{*}$ & Methylated & Unmethylated & Deregulated in colorectal cancer & NM_002711.2 & 38 \\
\hline & WISP3 & Methylated & Unmethylated & Loss of expression in inflammatory breast cancer & NM_003880.2 & 39 \\
\hline \multirow{7}{*}{$\begin{array}{c}\text { Genes enhancing } \\
\text { proliferation }\end{array}$} & ADORA3 & Methylated & Unmethylated & Activation of the NFKB pathway & NM_020683.5 & 15 \\
\hline & AIRE & Methylated & Unmethylated & Regulated by the PKC pathway & NM_000383.1 & 40 \\
\hline & CARD15 & Methylated & Unmethylated & Activation of the NFKB pathway & NM_022162.1 & 41 \\
\hline & $F A B P 7$ & Methylated & Unmethylated & Regulated by the MAPK/ERK pathway & NM_001446.3 & 42 \\
\hline & LOC340061 & Methylated & Unmethylated & Activation of the NFKB pathway & NM_198282.1 & 23 \\
\hline & PRF1 & Methylated & Unmethylated & Enhancing the MAPKinase pathway & NM_005041.3 & 16 \\
\hline & UNC5CL & Methylated & Unmethylated & Activation of the NFKB pathway & NM_173561.1 & 43 \\
\hline \multirow{3}{*}{$\begin{array}{l}\text { Genes facilitating } \\
\text { tumorogenesis }\end{array}$} & ANGPT2 & Methylated & Unmethylated & Preferentially expressed in unmutated CLL & NM_001147.1 & 28 \\
\hline & IFNBI & Methylated & Unmethylated & Shown to enhance B-cell proliferation & NM_002176.2 & 24 \\
\hline & $U R P 2$ & Methylated & Unmethylated & Implicated in facilitating CLL tumorogenesis & NM_031471.4 & 44 \\
\hline \multirow{2}{*}{$\begin{array}{c}\text { Anti-apoptotic } \\
\text { genes }\end{array}$} & $B C L 2$ & Methylated & Unmethylated & Known anti-apoptotic gene, up-regulated in many cancers & NT_025028.13 & 26 \\
\hline & PLD1 & Unmethylated & Methylated & Stimulates cell cycle progression by repressing $\mathrm{p} 53$ regulation of $\mathrm{p} 21$ & NM_002662.2 & 45 \\
\hline \multirow{2}{*}{$\begin{array}{c}\text { Pro-apoptotic } \\
\text { genes }\end{array}$} & $B C L 10$ & Unmethylated & Methylated & Pro-apoptotic genes, involved in p53 mediated cell death & NM_003921.2 & 17 \\
\hline & IL19 & Methylated & Unmethylated & Regulating apoptosis by activation of the STAT3 pathway & NM_013371.2 & 46 \\
\hline $\begin{array}{c}\text { Genes involved in } \\
\text { prognosis }\end{array}$ & $N G F R$ & Unmethylated & Methylated & Highly expressed in favorable prognostic ALL patients & NM_002507.1 & 29 \\
\hline
\end{tabular}




\begin{tabular}{|c|c|c|c|c|c|c|}
\hline $\begin{array}{l}\text { Functionality of } \\
\text { genes }\end{array}$ & $\begin{array}{l}\text { Gene } \\
\text { names }\end{array}$ & $\begin{array}{l}\text { IGHV } \\
\text { unmutated }\end{array}$ & IGHV3-21 & Implicated role in cancer & $\begin{array}{l}\text { Accession } \\
\text { number }\end{array}$ & Ref \\
\hline \multirow{5}{*}{$\begin{array}{l}\text { Tumor } \\
\text { suppressor } \\
\text { genes }\end{array}$} & $A B I 3^{*}$ & Methylated & Unmethylated & Lost in cancer cell lines, implicated in lung metastasis & NM_016428.3 & 21 \\
\hline & GPX3 & Methylated & Unmethylated & Deleted or methylated in prostate cancer & NM_002084.2 & 47 \\
\hline & $I G S F 4^{*}$ & Methylated & Unmethylated & Down-regulated by methylation in neuroblastoma & NM_014333.2 & 18 \\
\hline & SERPIND5 * & Methylated & Unmethylated & Tumor suppressive properties in breast cancer & NM_002639.2 & 48 \\
\hline & $S L C 22 A 18$ & Unmethylated & Methylated & Deregulated in several cancer forms & NM_183233.1 & 49 \\
\hline \multirow{2}{*}{$\begin{array}{l}\text { Genes repressing } \\
\text { proliferation }\end{array}$} & LDOC1 & Unmethylated & Methylated & Implicated in repressing the $\mathrm{NF} \kappa \mathrm{B}$ pathway & NM_012317.2 & 50 \\
\hline & ZNF540 & Methylated & Unmethylated & Involved in down-regulating the MAPKinase pathway & NM_152606.2 & 51 \\
\hline \multirow{4}{*}{$\begin{array}{l}\text { Genes facilitating } \\
\text { tumorogenesis }\end{array}$} & ILI7RC & Unmethylated & Methylated & Shown to facilitate tumorogenesis in prostate cancer & NM_032732.2 & 25 \\
\hline & ANGPT2 & Unmethylated & Methylated & Expressed in IGHV unmutated CLL & NM_001147.1 & 28 \\
\hline & FHL2 & Methylated & Unmethylated & & NM_201556.1 & \\
\hline & $S 100 A 14$ & Unmethylated & Methylated & & NM_020672.1 & \\
\hline \multirow{2}{*}{$\begin{array}{l}\text { Anti-apoptotic } \\
\text { genes }\end{array}$} & $B C L 2$ & Unmethylated & Methylated & Known anti-apoptotic gene, up-regulated in many cancers & NT_025028.13 & 26 \\
\hline & PLD1 & Methylated & Unmethylated & Stimulates cell cycle progression by repressing p53 regulation of $\mathrm{p} 21$ & NM_002662.2 & 45 \\
\hline
\end{tabular}




\begin{tabular}{|c|c|c|c|c|c|c|}
\hline Functionality & $\begin{array}{l}\text { Gene } \\
\text { names }\end{array}$ & $\begin{array}{l}\text { IGHV } \\
\text { mutated }\end{array}$ & IGHV3-21 & Implicated role in cancer & $\begin{array}{l}\text { Accession } \\
\text { number }\end{array}$ & Ref \\
\hline $\begin{array}{l}\text { Genes enhancing } \\
\text { proliferation }\end{array}$ & $\begin{array}{l}\text { LOC340061 } \\
\quad \text { PRF1 } \\
\text { RASGRP3 }\end{array}$ & $\begin{array}{l}\text { Methylated } \\
\text { Methylated } \\
\text { Methylated }\end{array}$ & $\begin{array}{l}\text { Unmethylated } \\
\text { Unmethylated } \\
\text { Unmethylated }\end{array}$ & $\begin{array}{l}\text { Activation of the NFKB pathway } \\
\text { Enhancing the MAPKinase pathway } \\
\text { Regulated B-cell proliferation by facilitating B cell receptor-RAS signaling }\end{array}$ & $\begin{array}{l}\text { NM_198282.1 } \\
\text { NM_005041.3 } \\
\text { NM_170672.1 }\end{array}$ & $\begin{array}{l}23 \\
16 \\
52\end{array}$ \\
\hline $\begin{array}{l}\text { Genes facilitating } \\
\text { tumorogenesis }\end{array}$ & $\begin{array}{c}L M O 2 \\
\text { URP2 } \\
\text { NCRMS }\end{array}$ & $\begin{array}{l}\text { Methylated } \\
\text { Methylated } \\
\text { Methylated }\end{array}$ & $\begin{array}{l}\text { Unmethylated } \\
\text { Unmethylated } \\
\text { Unmethylated }\end{array}$ & $\begin{array}{l}\text { Known proto-oncogene, expressed in human B-cell lymphomas } \\
\text { Implicated in facilitating CLL tumorogenesis }\end{array}$ & $\begin{array}{l}\text { NM_005574.2 } \\
\text { NM_031471.4 } \\
\text { XR_000219.2 }\end{array}$ & $\begin{array}{l}53 \\
44\end{array}$ \\
\hline $\begin{array}{l}\text { Pro-apoptotic } \\
\text { genes }\end{array}$ & $\begin{array}{l}\text { TP53I3 } \\
B C L 10\end{array}$ & $\begin{array}{l}\text { Methylated } \\
\text { Unmethylated }\end{array}$ & $\begin{array}{l}\text { Unmethylated } \\
\text { Methylated }\end{array}$ & $\begin{array}{l}\text { Shown to induce p53 mediated cell death } \\
\text { Pro-apoptotic genes, involved in p53 mediated cell death }\end{array}$ & $\begin{array}{l}\text { NM_004881.2 } \\
\text { NM_003921.2 }\end{array}$ & $\begin{array}{l}27 \\
17\end{array}$ \\
\hline $\begin{array}{l}\text { Genes involved in } \\
\text { prognosis }\end{array}$ & DNTT & Methylated & Unmethylated & Associated with poor prognosis in acute myeloid leukemia & NM_004088.3 & 54 \\
\hline
\end{tabular}

*These genes represent candidate tumor suppressor genes. 


\section{FIGURE LEGENDS}

Figure 1. Methylation indices (MI) for the 27 samples included in the present study.

Figure 2: Supervised hierarchical clustering of methylated/unmethylated genes between CLL subgroups. Three different comparisons were made: (A) IGHV mutated (samples M1 to M6) vs. IGHV unmutated (samples UM1 to UM7), (B) IGHV unmutated vs. IGHV3-21 (samples 3-21-1 to 3-21-10) and (C) IGHV mutated vs. IGHV3-21. Two normal healthy control samples and 1 negative control were included for comparison. A gradient color scale ranging between green (completely unmethylated) and red (completely methylated) is included.

Figure 3. Validation experiments using MSP-PCR. Methylation-specific PCR was performed for the PRF1, ADORA3, BCLIO and IGSF4 genes, using bisulfite treated DNA from IGHV mutated samples (M1-3 to M8-12) and IGHV unmutated samples (UM1-4 and UM8-12). Figure $3 \mathrm{~A}$ shows data for samples analyzed in the methylation array whereas Figure 3B includes results from additional CLL samples. Analysis of each gene in Figure 3A/B was performed during the same experiment and on the same gel, vertical line(s) have been inserted to indicate a repositioned gel lane. N: normal PBMC sample; M: methylation-specific primers; U: unmethylation-specific primers.

Figure 4. Validation experiments using quantitative RT-PCR. Relative expression data presented as box plots for the following genes: $V H L, A B 13, A D O R A 3$ and BCL10. 27 IGHV unmutated and 23 IGHV mutated CLL cases were investigated that had been not included in the methylation array analysis. p-values are indicated above each box plot. Boxes indicate the 
interquartile range (25-75\%) with the smaller inner square indicating the median. The whiskers show the minimum and maximum values, except for outliers (circles).

Figure 5. Bi-sulfite sequencing of 2 tumor suppressor genes. (A) $V H L$ and (B) $A B 13$. Results from 2 IGHV mutated and 2 IGHV unmutated CLL samples are shown. Black lollipops; methylated CpG sites and white lollipops; unmethylated CpG sites. $\star$ Indicates a polymorphic site.

Figure 6. RT-PCR analysis showing the re-expression of methylated tumor suppressor genes in unmutated CLL. Three different candidate tumor suppressor genes, (A) IGSF4, (B) AB13 and (C) VHL were investigated in 3 IGHV unmutated CLL samples (UM1 to UM3, shown in different colors) with and without treatment using the methyl inhibitor 5-aza-2'-deoxycytidine (DAC), the histone deacetyl (HDAC) inhibitor, Trichostatin A (TSA) or in combination. Con, control. 
FIGURE 1

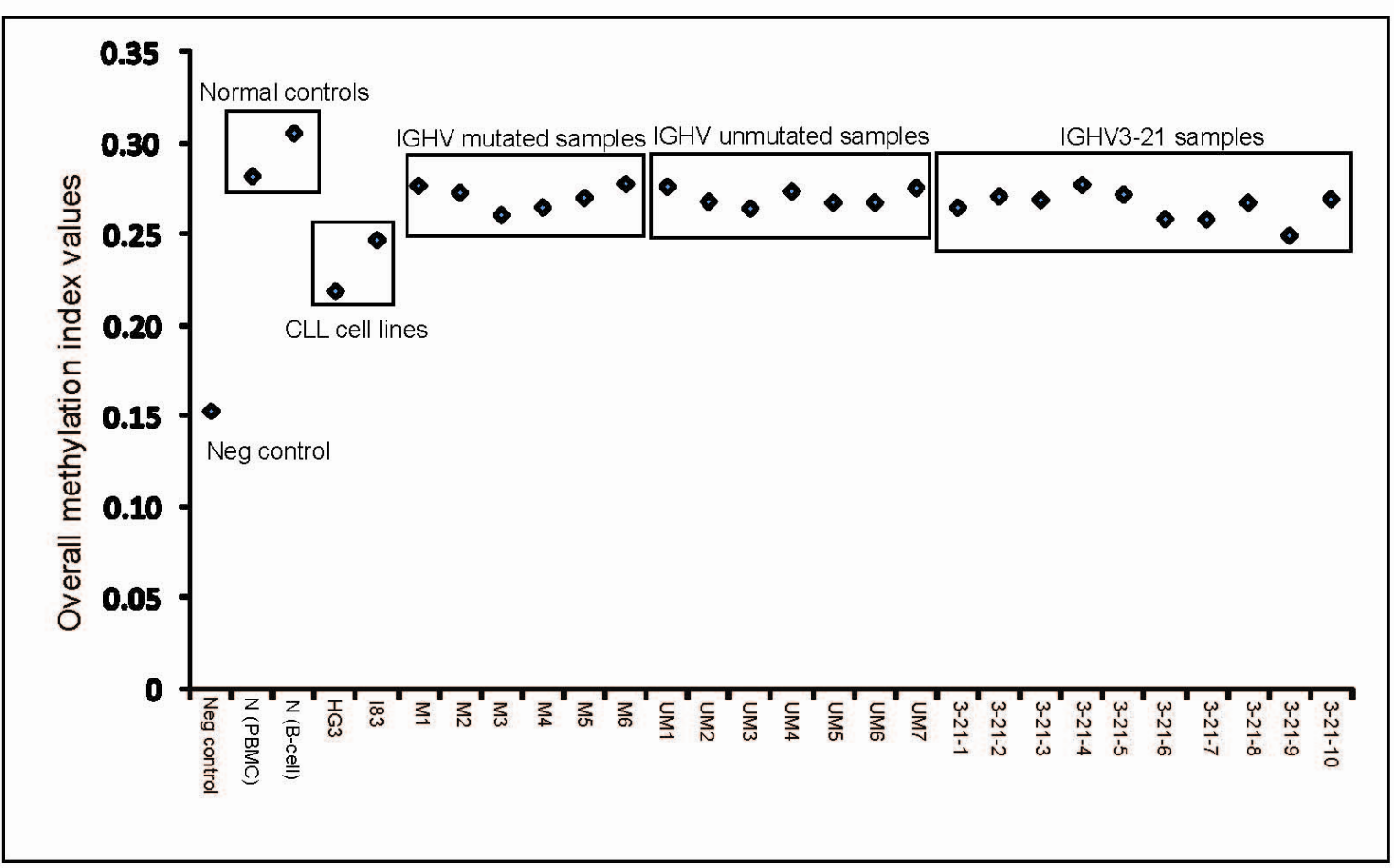


FIGURE 2

A

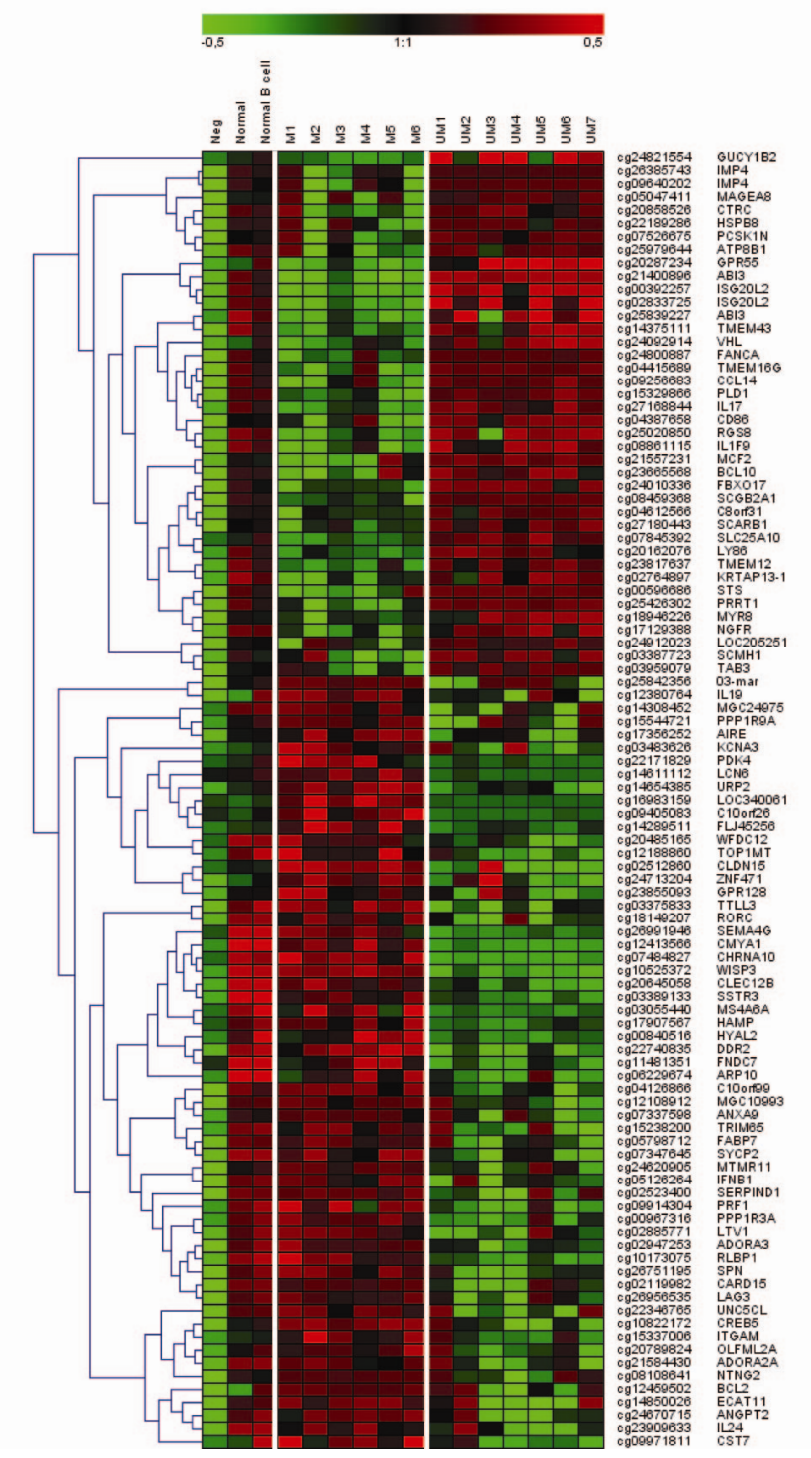

B

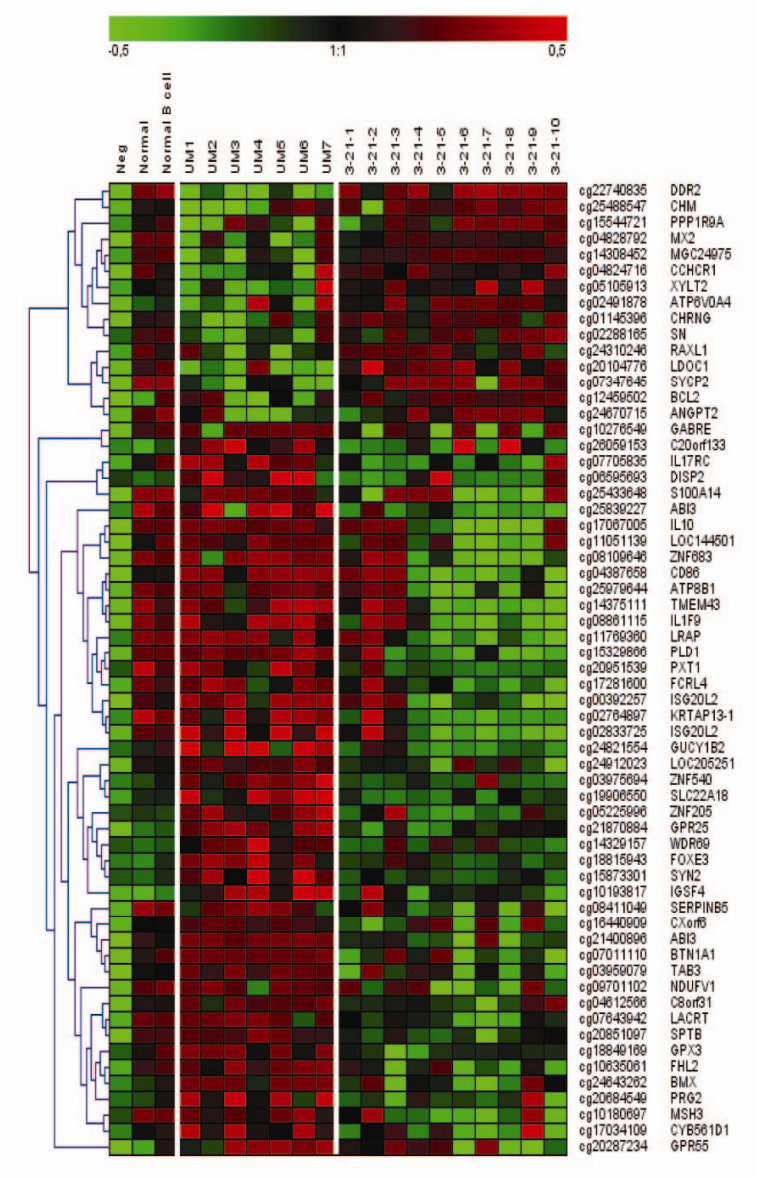

C

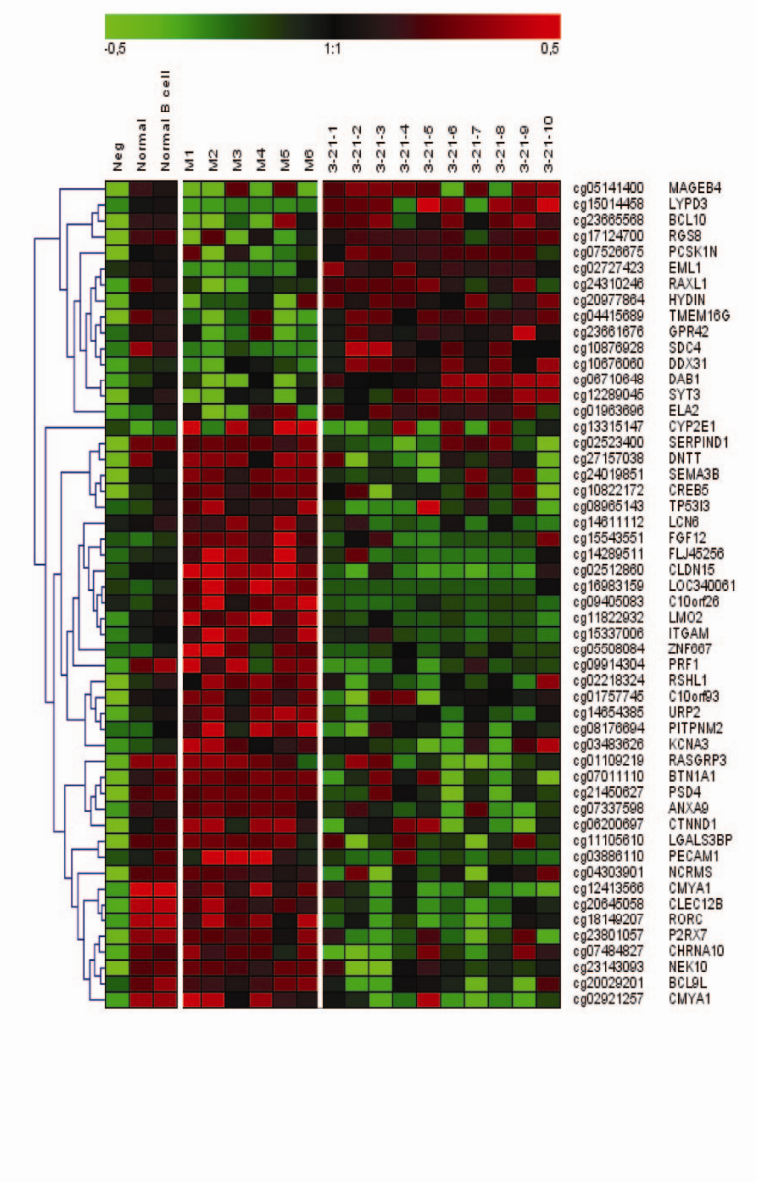


FIGURE 3

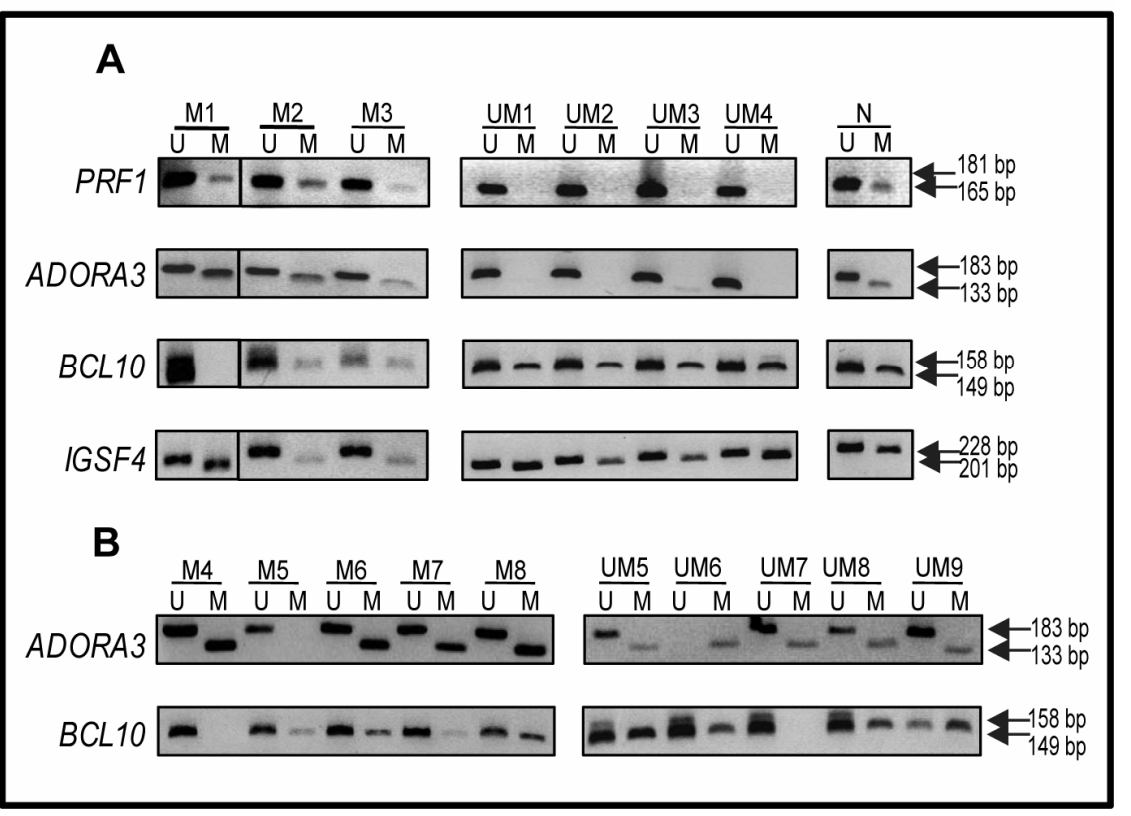


FIGURE 4

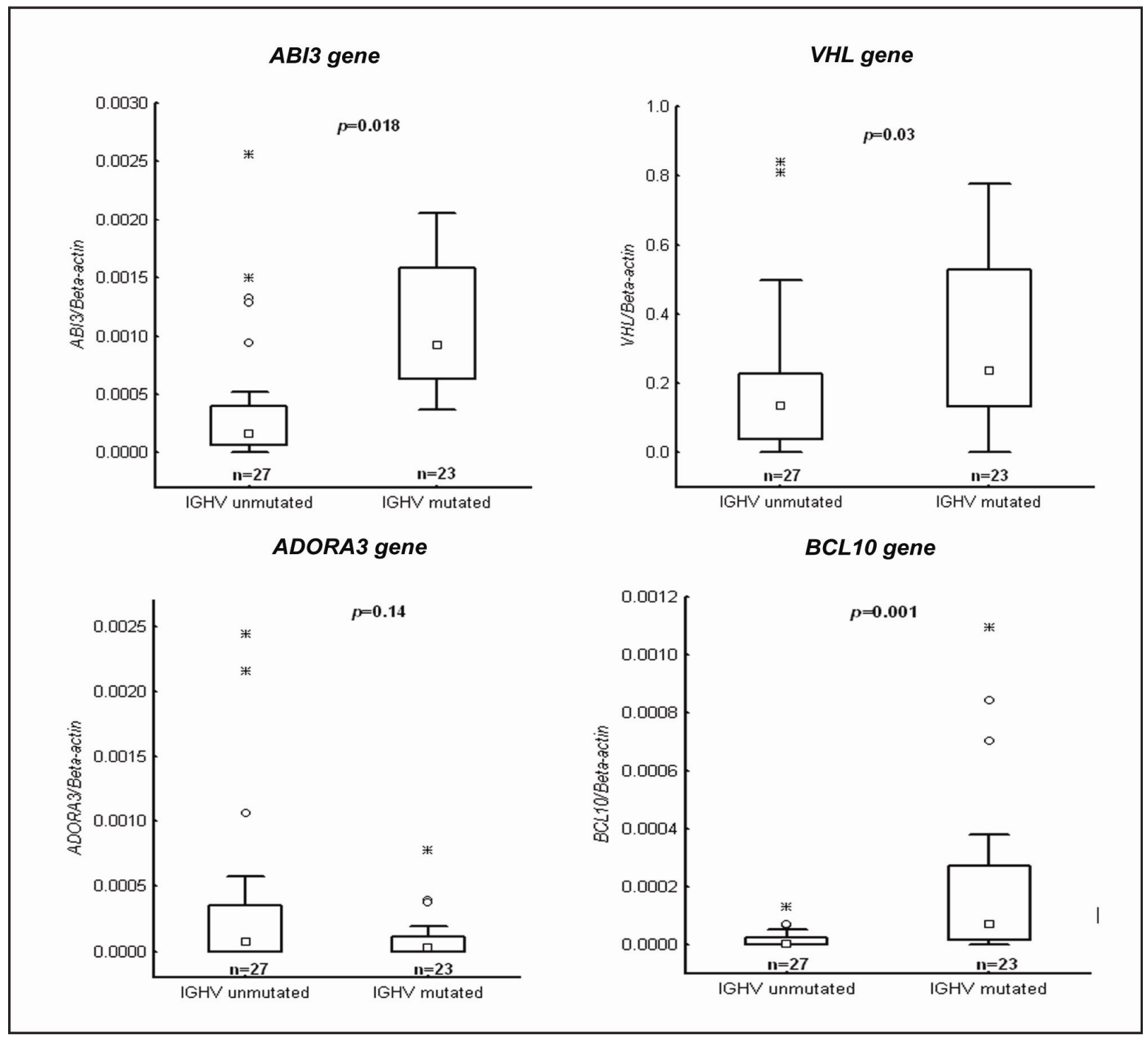


FIGURE 5

A

\begin{tabular}{|c|c|c|c|}
\hline \multicolumn{4}{|c|}{ VHL gene } \\
\hline 오, & ㅇ, poppop & & \\
\hline 오, 9000,0 & 오, 이이이 & & \\
\hline ㅇ, 900,00 & 오, , 이이오 & & \\
\hline 오, 오이, 오 & 오, 이우이오 & & \\
\hline Q, 9090909 & 오, popopere & & \\
\hline Q, popopop & 오, popoper & & \\
\hline Q, 9,9, , & 오, , & & Q요 \\
\hline $0,00,00$ & ㅇ, , , & & \\
\hline 오, 오우, 소 & 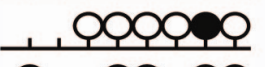 & & \\
\hline Q, $9,0,90$ & ק, ب, & & \\
\hline $\begin{array}{c}\star_{\text {Mutated }} \\
\text { sample } 1\end{array}$ & $\begin{array}{l}\star \text { Mutated } \\
\text { sample } 2\end{array}$ & $\begin{array}{l}\text { Unmutated } \\
\text { sample } 1\end{array}$ & $\begin{array}{l}\text { Unmutated } \\
\text { sample } 2\end{array}$ \\
\hline
\end{tabular}

B

\begin{tabular}{|c|c|c|c|}
\hline \multicolumn{4}{|c|}{$A B / 3$ gene } \\
\hline ㅇp오오 & ppopop & 오오 & \\
\hline popop & poppop & 오이 & \\
\hline pQpopo & poppop & & \\
\hline 오이오 & popop & 오. & \\
\hline pQpopol & QpQpop & 소. & \\
\hline 오우오 & 900000 & & \\
\hline ㅇp이오 & 오우오 & 보 & \\
\hline pQpopop & poppop & & \\
\hline pQpopo & ppoppos & 오 & \\
\hline 오이오 & 오이오 & Pبper & \\
\hline 오이요 & 우이오 & Pب9 & \\
\hline popoo & popop & Pبeper & \\
\hline $\begin{array}{l}\text { Mutated } \\
\text { sample } 1\end{array}$ & $\begin{array}{l}\text { Mutated } \\
\text { sample } 2\end{array}$ & $\begin{array}{l}\text { Unmutated } \\
\text { sample } 1\end{array}$ & $\begin{array}{l}\text { Unmutated } \\
\text { sample } 2\end{array}$ \\
\hline
\end{tabular}


FIGURE 6
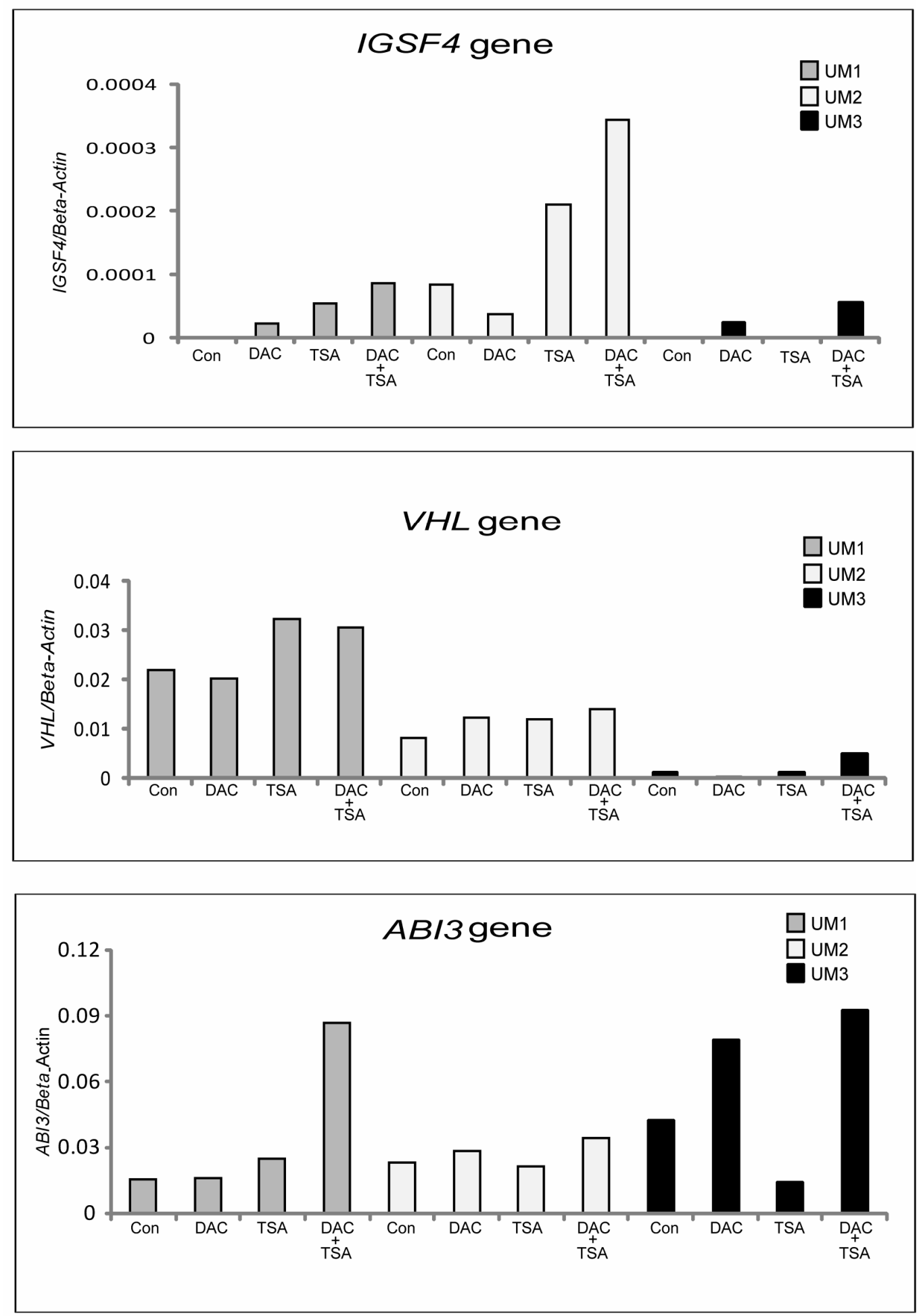